\title{
The interpersonal cognitive problem solving approach for preschoolers
}

\author{
Selahiddin Öğülmüş \\ Ankara University, Ankara, Turkey, s.ogulmus@gmail.com
}

Eda Karg1

Eastern Mediterranean University, Famagusta, Turkish Republic of Northern Cyprus, eda.kargi@ gmail.com

\begin{abstract}
Children's ability to produce effective solutions to the problems related with their interpersonal relationships in their daily lives and to develop these problem-solving skills is closely concerned with their level of social adaptation and emotional satisfaction. It is observed that children who display behavior problems in preschool education settings usually lack interpersonal problem-solving skills. These skills are teachable to teachers and parents to help children learn I Can Problem Solve (ICPS) skills and how to use those when real problems came up. Children could learn ICPS skills and generalize them their newly acquired skills. ICPS is an extremely promising approach for promoting pro-social competence. Prevention of behavior problems in children and because of the for development of social competence is an important issue many of these models is needed to identify. This article describes the results of studies in different cultures, the interpersonal problem solving models based.
\end{abstract}

Keywords Interpersonal problem solving, social skills, thinking skills,preschool education

\section{Okul öncesi dönemdeki çocuklar için kişilerarası sorun çözme yaklaşımı}

ÖZET Çocukların, gündelik yaşamlarında kişilerarası ilişkilerinde yaşadıkları sorunlara etkin çözümler üretebilmeleri, onların toplumsal uyum düzeyleri ve duygusal doyumları ile yakından ilişkilidir.

Okul öncesi eğitim ortamlarında davranış sorunları gösteren çocuklarda genellikle kişilerarası sorun çözme becerilerinin eksikliği gözlenmektedir. Bu becerilerin eksikliği, çocukların akranları ile ve yetişkinlerle olan olumlu etkileşimlerinin gelişimini engellemektedir. Kişilerarası ilişkilerde sorun çözme becerileri öğrenilebilir ve öğretilebilir. Bu beceriler yaşamda bu tür sorunlar ortaya çıktığında çocukların sorun çözme becerilerini kullanabilmeleri için, öğretmenler ve anne babalar tarafından çocuklara öğretilebilir. Çocuklar edindikleri sorun çözme becerilerini, yeni kazandıkları becerilere genelleyebilirler. Kişilerarası sorun çözme becerileri, çocuklarda pro-sosyal davranışların ve bu yolla da toplumsal yeterliğin gelişimi için son derece destekleyici bir yaklaşımdır. Çocuklarda davranış sorunlarının önlenmesi ve toplumsal yeterliğin gelişiminin güçlenmesi için, başta Ben Sorun Çözebilirim (BSÇ) kişilerarası ilişkilerde sorun çözme yaklaşımı olmak üzere, çeşitli modeller ve yaklaşımlar vardır. Bu makalede, araştırmaların sonuçları, kişilerarası sorun çözme modelleri ekseninde açıklanmaktadır.

Anahtar Közçikler Krilerası sorun çözme, sosyal beceriler, düşünme becerileri, okul öncesi eğitim 


\section{GENIŞLETILMIŞ ÖZET}

İnsanın bedensel, zihinsel, duygusal ve sosyal gelişimi karşıllklı olarak birbirini etkiler ve gelişim bir bütündür. Örneğin bir çocuğun yaşamı boyunca toplumsal ve duygusal yönden uyumlu bir birey olması, onun akademik başarısını etkilemektedir. Gelişim, çocukların okul öncesi dönemde yaşıtlarıyla ve yetişkinlerle bir arada olmaları, ortak yaşantıları paylaşarak deneyim kazanmaları ve sosyal becerilerini güçlendirmeleri ile mümkündür (Fan ve Chen, 2001). Bireylerin toplum içinde bağımsız olarak yaşayabilmeleri ve yaşam kalitelerini arttırabilmeleri çoğunlukla kurdukları kişiler arası ilişkilere ve etkileşimlerin niteliğine bağlıdır. Kişilerarası etkileşim, tarafların duygu, düşünce ve davranışlarını olumlu ya da olumsuz yönde etkileyebilen ve karş1lıklılık içeren bir süreçtir (Öğülmüş, 2001). İnsan, birbirine benzeyen ve farklılaşan hatta çatışan gereksinimleri olan bireylerin oluşturduğu karmaşık bir toplumda yaşamayı öğrenmeye ve diğer bireylerle karşılıklı etkileşim halinde olmaya, yaşam boyu gereksinim duyar. Toplumsal yeterlik, bireyin karşılaştığı sorun içeren durumlara yanıt verebilme potansiyelinin etkililiğini ifade etmektedir. Zigler (1972), etkililiği çevre ile baş edebilme konusundaki etkililik olarak tanımlamaktadır. Bu açıklamalardan da anlaşıldığı üzere, toplumsal yeterlik, kişlerarası ilişkileri ve sorun çözme becerilerini kapsayan bir beceridir. Vygotsky'e göre psikolojik gelişim, toplumsal düzlemden, bireysel düzleme doğru ilerlemektedir. Toplumsal dünya çocuğun gelişimine rehberlik eder, toplum anababalara ve öğretmene özel bir rol yüklemektedir (Miller, 1993). Çocuğun bilişsel gelişimini izlemek ve anlamak için kültürel tarihini ve geçmiş deneyimlerini bilmeye ihtiyaç vardır. Bu bağlamda, bilişsel gelişim toplumsal etkileşimlerde bulunmayı gerektirir. Bilişsel yaklaşıma dayalı olarak Shure (1992) tarafindan geliştirilen "Ben Sorun Çözebilirim" (I Can Problem Solve) programı, bireylere kişiler arası sorun çözme becerileri kazandırmayı amaçlayan bir programdır. $\mathrm{Bu}$ yaklaşım temel olarak çocuklarda toplumsal katılımın ve uyumun araçları olarak farklı düşünme becerilerine odaklanmıştır. Yaklaşımın en önemli özelliği, çocuklara sorun çözmeye ilişkin karar verme sürecinde ne yapacaklarını ya da ne düşüneceklerini değil, nasıl düşüneceklerini öğretmesidir. Shure ve Spivack'ın (1982) "Kişiler Arası Problem-Çözme ve Klinik Teori” olarak adlandırdıkları modelde gösterilmiştir ki eğer çocuklar tipik günlük sorunları çözmeyi öğrenebilirlerse dürtüsel (impulsif), içe kapanık, saldırgan veya antisosyal davranma olasılıkları azalır. Bu davranışların erken dönemde önlenmesi çok önemlidir, çünkü Parker ve Asher'a (1987) göre ileriki yıllarda sorunlu akran ilişkileri ve bireysel uyum sorunları konusunda bu öncü davranışların ciddi sorunlara zemin hazırladığı bilinmektedir.Eğitimciler ve klinisyenler duygusal gerilimin hafiflemesinin bireyin doğru düşünmesine yardım edebileceğini iddia etseler de, BSÇ (Ben Sorun Çözebilirim) modeli, doğru düşünme yeteneğinin duygusal gerilimi hafiflettiği görüşünü desteklemektedir. Sorun çözme ön becerilerinden aynı ve farklı kelimeleri, çocukların "FARKLI insanlar AYNI şey hakkında FARKLI duygular hissedebilirler" şeklinde düşünmelerie yardım edecek olan sorun çözme sözcükleridir. Ayrıca çocuklar, bu sözcükler aracılığıyla aynı sorunu çözmek için farklı yollar olduğunu da öğrenmektedirler.Webster-Stratton, Reid ve Hammond (2001) yaşları 4-8 arasında değişen ve davranım bozukluğu sorunu yaşayan 99 çocukla çalışmışlardır. Deney ve kontrol gruplarına yansız olarak atanan çocuklardan deney grubunda olanlara sosyal beceri eğitimi ve sorun çözme eğitimi verilmiştir. Eğitim sonrasında deney grubundaki çocukların ev ortamında dışa yönelim sorunlarında anlamlı bir şekilde azalma meydana gelmiştir. Bu çocuklar okulda daha az saldırgan davranışlar göstermişler ve daha olumlu sorun çözme stratejileri geliştirmişlerdir. Bir yıl sonra yapılan izleme çalışmasında, eğitimlerden sonra gözlemlenen anlamlı değişimlerin büyük bir çoğunlukla sürdüğü belirlenmiştir.Kişiler arası ilişkilerde sorun çözme becerisi okul öncesi dönemde desteklenmesi gereken ve etkileri tüm yaşam boyu süren bir beceridir. Bu nedenle kişiler arası sorun çözme becerileri ve özellikle de bu becerilerin çocuklara öğretilmesi konusunda gittikçe artan bir ivmeyle çeşitli araştırmalar yapılmaktadır. Araştırmalar, çocukların bu beceriyi 4 yaşından itibaren kazanabileceğine ilişkin bilimsel kanıtlar sunmaktadır (Shure, 2001).Hune ve Nelson (2002), öğretmenlerin gözlemlerine dayalı olarak, antisosyal davranış sorunları geliştirme konusunda riskli davranışlar gösteren 4-5 yaşlarındaki çocuklarla bir araştırma yapmışlardır. Araştırmacılar bu davranışları itme, vurma gibi yıkıcı davranışlar olarak tanımlamışlardır. Araştırma sonucunda eğitim verdikleri grubun, eğitim almayan gruba oranla, daha fazla olumlu sosyal davranışlar içeren çözümler ürettiğini ve bu çocukların saldırgan davranışlarında azalma olduğunu saptamışlardır.Erwin, Purves ve Johannes (2005), 7-8 yaş grubu 31 ilköğretim öğrencisi çocukla çalışmışlardır. Katılımcıların 16's1 deney grubuna, 15 'i de kontrol grubuna atanmışlardır. Deney grubuna 3 hafta boyunca 6 ders BSÇ (sorun çözme) eğitimi verilmiştir. Eğitimler süresince deney grubundaki çocuklar kendi aralarında 
seçkisiz olarak 4 ya da 5 kişilik küçük alt gruplara ayrılmışlardır. Çocuklar üç sosyal çatışma durumunda alternatif çözüm üretme ve sonucu dikkate alarak düşünme boyutlarında değerlendirilmişlerdir. Araştırma sonucunda deney ve kontrol gruplarının son testleri arasında deney grubundaki çocuklar lehine anlamlı bir farklılık saptanmıştır. Ayrıca alternatif çözüm üretme ve sonucu dikkate alarak düşünme puanları arasında da anlamlı ilişki olduğunu saptamışlardır. Sonuç olarak, BSÇ eğitiminin alternatif çözümler üretme ve sonucu dikkate alarak düşünme becerileri üzerinde etkili olduğu belirlenmiştir. $\mathrm{Bu}$ araştırmada eğitim grubunda olan çocuklar eğitim almayan kontrol grubundaki çocuklara oranla anlamlı bir şekilde ilerleme göstermişlerdir. Bu sonuçlar grup ikliminin olumlu yönde geliştirilmesi açısından da BSÇ eğitiminin önemine dikkat çekmektedir. Araştırmacılar, genellikle müdahale temelli yaklaşımların sosyal davranışsal sorunların önlenmesinde etkili olduğu ve bu müdahalelerin erken yıllarda yapılması gerektiği konusunda görüş birliği içindedirler (Loeber, 1990; Walker, Colvin ve Ramsey, 1995; Walker ve Sylwester, 1991). BSÇ programının etkililiğine ilişkin, Karg1 (2009), tarafindan yürütülen bir diğer çalışmada da, kişiler arası sorun çözme becerileri eğitimi alan çocukların sorun çözme beceri puanlarının kontrol grubuna oranla anlamlı bir şekilde yüksek olduğu, deney grubunda yer alan çocukların sorun davranışlarının da anlamlı bir şekilde azaldığı saptanmıştır. Araştırma bulgularına dayalı olarak çocuklara verilen kişiler arası sorun çözme becerileri eğitiminin çocukların sorun çözme becerilerini geliştirme ve davranış sorunlarını azaltmada etkili olduğu belirlenmiştir. Ayrıca sorun çözme ve sorun davranış değişkenleri arasında bir ilişki olduğu, ancak çocukların anne-çocuk sorunlarına ve akran sorunlarına ilişkin olarak önerdikleri kategori ve çözüm sayılarının sorun davranışların anlamlı bir yordayıcısı olmadığı saptanmıştır.Son yıllarda çocuk, aile ve okullara yönelik önleme çalışmalarına ilişkin yapılan araştırmalarda önemli bir ilerleme kaydedilmiş ve psikolojik belirtilerin azaltılmasında etkililiği kanıtlanmış programların sayısı artmıştır. Duygusal ve davranışsal sorunları olan çocuk ve ailelerin yaşadıkları bireysel zorlukların yanı sıra, ruh sağlığı sorunlarının toplum için de bedeli ağırdır. Çocukluk dönemi ruhsal sorunlarının azaltılması için, müdahalenin erken dönemlerde, belirtiler ortaya çıkmadan önce başlatılması gerekmektedir. 


\section{INTRODUCTION}

Pre-school education aims at contributing to the child's physical, cognitive, emotional and social development; and thus growing healthy children who are able to realize their potentials. These aspects of development are closely related to each other. For a child to be a socially and emotionally adaptable individual throughout the life influences his/her cognitive functions and academic achievement. For individuals to live independently within the society and to increase their quality of life is mostly dependent on their interpersonal relationships. Pre-school education also develops the social skills and social competence of children. Social skills enable the individual to adapt to the society, to integrate with the society, and to communicate with his/her peers and other individuals. In addition, they improve academic skills and facilitate the rise of achievement in these skills. Social competence is the effectiveness of the potential of an individual in reacting to encountered issues. According to Zigler, Bella \&Watson (1972), however, it is the effectiveness in dealing with the enviroment. As indicated by these explanations, social competence has the quality of including interpersonal relationships and problem solving skills. Interpersonal Cognitive Problem Solving (ICPS) approach has been developed by Myrna Shure and this program includes some critical skills supporting the development of social competence.There is a consensus on the issue that the individuals who are skillful in social behaviors gradually become productive, respectable and successful individuals. For instance, Heppner et al. (1983) have studied the cognitive differences between children's self-evaluations. It was found that the children who consider themselves to be effective problem solvers have more positive self-concept, know themselves better and criticize themselves less than the others do.

\section{Problem Solving as a Social Skill}

The human needs to learn to live in a complex society composed of individuals who have similar, different and even conflicting needs, and to interact with other individuals. This interaction is a process which contains reciprocity that might influence the parties' emotions, thoughts and behaviors in positive or negative ways (Öğülmüş, 2001).

Vygotsky emphasizes on social interactions as the sources of development (Karpov, 2003). According to Vygotsky, the psychological development moves from the social level to the individual level. The social world guides the child's development (Miller, 1993).

In order to understand the child's development, it is needed to understand how the child is grown in the society. According to Vygotsky, the system of thinking is not a product of only the internal factors but also of the cultural institutions and social interactions. Children learn the cultural facts through social activities. In this respect, the cognitive development needs social interactions.

Gardner (2006) argues that the respectful mind sees and respects the inter-individual and inter-group differences, since it is impossible today for a person to maintain a life in seclusion from others. The respectful mind tries to understand "others" and seeks ways to cooperate with them. Gardner (2006) suggests that the reactions such as respecting others emerge in the very early periods of life.

Table 1. Using Problem Solving Skills

\begin{tabular}{ll}
\hline \multicolumn{1}{c}{ Developmental Indicators } & \multicolumn{1}{c}{ Example behaviors } \\
\hline 1. Discovering problems & The child may express / define his/her personal problems \\
\hline $\begin{array}{l}\text { 2. Making efforts to solve } \\
\text { the problems }\end{array}$ & $\begin{array}{l}\text { The child may modify his/her acts according to a new information or a new } \\
\text { situation (e.g: may change the construction against the threat of downfall or } \\
\text { vibration of the blocks in the construction game). } \\
\text { The child may modify his/her behaviors according to the reactions of other } \\
\text { children or adults. }\end{array}$ \\
\hline $\begin{array}{l}\text { 3. Working with others to } \\
\text { solve problems }\end{array}$ & $\begin{array}{l}\text { The child cooperates with others in making decisions (e.g: may decide which } \\
\text { game to play with friends). } \\
\text { Suggests solutions to the problems with other children, decides whose turn is } \\
\text { first and next. }\end{array}$ \\
\hline
\end{tabular}


Table 2 Taking Initiatives / Entrepreneurship

\begin{tabular}{ll}
\hline \multicolumn{1}{c}{ Developmental Indicators } & \multicolumn{1}{c}{ Examples } \\
\hline \multirow{2}{*}{ 1. Starting interpersonal relations with others } & $\begin{array}{l}\text { Invites his/her friends to the game. } \\
\text { Joins the game while the friends are playing. } \\
\text { Participates in group activities } \\
\text { Suggests new game activities. }\end{array}$ \\
\hline \multirow{3}{*}{ 2. Making decisions independently } & $\begin{array}{l}\text { May select the materials for the project } \\
\text { Assists others. } \\
\text { Warns others when they make mistakes, corrects their mistakes. }\end{array}$ \\
3. Presents autonomous behaviors during & $\begin{array}{l}\text { Hangs his jacket up when s/he arrives at school. } \\
\text { Likes to often play alone. } \\
\text { activities, training routines and games. }\end{array}$ \\
Accomplishes the task given/ finishes the task s/he started.
\end{tabular}

A model about how children use their problem solving skills is presented in the Table 1 with developmental indicators and example behaviors, and the developmental indicators related to taking initiatives/ entrepreneurship are presented in the Table 2. The model contains a cyclical structure about developing expectations towards producing solutions, defining the problem, producing solutions with tools such as producing alternatives and negotiation in the dimensions of thinking and behavior, and what should be taken into consideration in situations of agreement and disagreement.

\section{The Interpersonal Cognitive Problem Solving Program for Preschoolers}

The "I can Problem Solve" program, which is based on the cognitive approach and aims at providing individuals with interpersonal problem solving skills, was developed by Shure (1992).

This education approach has been especially applied to children. The approach basically emphasizes on different thinking skills as the tools of social participation and adaptation in children. The most important feature of the approach is that it teaches children how to think, rather than what to do or what to think, in the decision-making process related to problem-solving.

The ICPS approach is widely used with children and adults in places such as schools and hospitals. The problems are diverse; such as impulsivity, hyperactivity and social exclusion in children and adolescents, and increasing problems in social interactions and interpersonal relations in adults. Though it has a wide application area, most of the ICPS researches focus on children and especially little children. One of the advantages of this method is that it is easy to include it in pre-school or elementary school programs. It prevents little problems to grow up.

The ICPS programs contain various social-cognitive skill, and for instance, preschool version of ICPS Program includes 59 lessons in Table 3. The ICPS researchers focus generally on two main thinking skills. These are; finding alternative solutions and thinking by considering the result. These two thinking skills seem to be closely related to the adaptation of small children. Children who are weak in finding alternative solutions and who show impulsive and aggressive behaviors implement only one strategy to attain what they desire and to solve the problems that they face, and thus, they show the tendency to use force when they fail (Erwin et al., 2005).

New approaches to analyze behavioral problems in children use the social skill training as an intervention tool especially in alleviating interpersonal problems.

A significant relationship has been found between children's pre-social problem solving strategies in the pre-school period and their social acceptances in the kindergarten and even in the first or second grades of the primary school. In addition, it is accepted that a relationship exists between social cognition and social behavior, and thus the peer acceptance is an important variable to comprehend these relationships in children's nature (Miller-Musun, 1993).

As Spivack and Shure's "Inter-Personal Problem Solving and Clinical Theory" model indicates, if children are able to learn how to solve typical everyday problems, they will less likely be impulsive, introvert, aggressive or antisocial. It is very important for these behaviors to be prevented in adolescence. Although educators and clinicians argue that the alleviation of emotional stress may help the individual's right thinking, the ICPS suggests the opposite, that is, the right thinking skill alleviates the emotional stress. 
Table 3. The Content of Problem Solving Skills Training Program

\begin{tabular}{|c|c|}
\hline Courses & Problem Solving Pre-Skills \\
\hline $1-10$ & Teaching the vocabulary of the program (IS, IS NOT, SOME-ALL, SAME-DIFFERENT) \\
\hline $11-18$ & Assisting children to know their and others' emotions (HAPPY, SAD, ANGRY) \\
\hline $19-22$ & Encouraging the children to develop skills related to listening and paying attention \\
\hline $23-28$ & Introducing the concepts of WHY-BECAUSE, MAYBE-PERHAPS to the children \\
\hline $29-31$ & Teaching to acknowledge individual differences and learn others' choices. \\
\hline $32-33$ & Helping children to figure out what is HONEST or JUST or not.. \\
\hline $34-38$ & $\begin{array}{l}\text { Alternative solutions: Helping children to understand what the problem is and to learn to produce } \\
\text { numerous possible solution producing ways. }\end{array}$ \\
\hline $39-50$ & $\begin{array}{l}\text { Possible solutions: Helping children to learn sequential thinking as the pre-requisite to understand } \\
\text { cause-effect relationships. }\end{array}$ \\
\hline $51-59$ & $\begin{array}{l}\text { Matching the possible solutions with the possible effects: Providing children with the possibility } \\
\text { to practice to see the linkage between a possible solution and a possible effect. }\end{array}$ \\
\hline
\end{tabular}

According to Shure (1996), the ICPS helps children in;

Thinking about what to do when they have problems with another person,

Thinking about different solutions to solve the same problem,

Thinking about the possible results of what they do,

Deciding if an idea is good,

Comprehending that other people have emotions and thinking about their emotions.

Among the problem solving pre-skills, the words of "same" and "different" are the problem solving words that will help children to think in the way of "DIFFERENT people may feel DIFFERENT about the SAME thing". Moreover, children learn that there exist different ways to solve the same problem.

It is suggested that several negative problem behaviors which are not approved by the society (lack of impulsive control, inability to postpone pleasure, inadequacy in coping with failure, corrupted friend relations, low empathy skill etc.) start in the pre-school period; thus it is important to put emphasis on preventing social behavioral problems at early ages.

\section{Problem Solving Training and Behavioral Disorders}

Webster-Stratton, Reid and Hammond (2001) worked with 99 children who were between 4-8 years of age and having behavioral disorder. Those who were in the experimental group were given social skill training and problem solving training. After the training, a significant decrease was observed in the extroversion problems of the children in the experimental group in the home environment. They presented less aggressive behaviors and developed more positive problem solving strategies at school. In the follow-up study conducted one year later, it was observed that the significant changes after the training were still present.

In a study aiming at decreasing aggressive behaviors in pre-school children, the teachers were taught rational methods that they can use while dealing with children who present aggressive behaviors. After this training, when children presented aggressive behaviors, the teachers gave them instructions in which they explained that hitting others may cause injuries, the children will not like those who hit them, and it is better to think about alternatives rather than hitting. Further observations indicated that the aggression in these children has decreased compared to others who had not received the above mentioned instructions and their cooperation with peers has increased (Zahavi and Asher, 1974, quoted by Urbain and Kendall, 1980).

Oden and Asher (1977) oriented $3^{\text {rd }}$ and $4^{\text {th }}$ grade students who were socially alone with a three-step social skill training program. After the study, it was found that the trained children were sociometrically more accepted by their friends. In the follow-up study, it was determined that the skills that had been taught were used and continuing to improve.

There are numerous studies on the effectiveness of the social skill training. For example, in a study conducted by Lochman, Coie, Underwood and Terry (1993), the effect of the social skill training program on aggressive and non-aggressive two groups of children rejected by their friends was examined. It was found in this study that the examined social skill training program had influence on 
aggressive and rejected children, the aggressive behaviors of these children have decreased, they were less rejected and their friendship relations have increased.

The problem-solving skill in interpersonal relations is a skill which must be supported during the preschool period and whose effects last throughout the entire life.

Hune and Nelson (2002), based on teachers' observations, conducted a study on children aged 4-5 years and showing risky behaviors in terms of developing antisocial behavioral problems. After the study, they have found that the trained group produced solutions that contain more of positive social behaviors and their aggressive behaviors have decreased, compared to the other group which had not been given training.

Erwin et al. (2005) worked with 31 elementary school children aged 7-8 years. The experimental group was given six sessions ICPS training during three weeks. The children were assessed in the dimensions of producing alternative solutions and thinking by considering the result in three social conflict situations. After the study, a significant difference was found between the post-tests of experimental and control groups in favor of the experimental group. A significant relationship was also found between the points of producing alternative solutions and thinking by considering the result. The researchers are in consensus on the fact that the intervention-based approaches are generally effective in preventing social behavioral problems and these interventions need to be done in early years (Loeber, 1990; Walker, Colvin and Ramsey, 1995; Walker and Sylwester, 1991).

\section{Problem Solving Training and Interpersonal Relations}

It has been determined that improving children's skills to produce effective solutions to everyday social problems is closely related to the social adaptation level, emotional satisfaction and happiness. Researches have also determined that, as a result of improving interpersonal problem solving skills, several characteristics of children have improved such as role taking skills, leaning to positive social behaviors, increasing in-group functionality in the classroom, focus of control, general social adaptation and peer acceptance (Erwin, 1993). Dinçer (1995) have determined that the alternative solution suggestions that the children who were aged 5 years and given interpersonal cognitive problem solving training produced against interpersonal problems in the dimensions of mother-child problems and peer problems were significantly higher than those of children who were not trained.

Along with the Spivack and Shure's traditional method, it has been observed that numerous short-term intervention methods have created effective changes in children's cognitive skills.

It is observed that the children who exhibit behavioral problems in pre-school education environments mostly lack social skills and interpersonal problem solving skills. The lack of social skills in the early period is closely related to the school achievement, interpersonal relations, and adult functionality problems in the consequent years (Parker and Asher, 1987). Answering the demands of the social environment usually requires problem solving (Durlak, 1983). The children who are unable to develop these skills are rejected by their peers and have negative interactions with adults (Wittmer et al., 1996). These negative experiences negatively affect children to develop positive social behaviors, to improve problem solving skills and their academic achievements.

It is suggested that those children who have interpersonal problem solving skills are disappointed less, show less anger when they fare ill, are not aggressive, consider other people more, are more eager to share and are more able to make friends (Shure, 1996).

The possibility for the children who have not learned how to solve interpersonal problems that they face in their daily lives to behave impulsive, introvert, aggressive or antisocial is higher. However, it is very important for such behaviors to be prevented in the pre-school period, because it is known that these pioneer behaviors pave the way for more serious problems in the development of peer relationships and further personal adaptation skills.

Shure and Spivack (1982), based on the findings that they got from many studies that they conducted, suggest that as children learn to solve the problems that they face in their interpersonal relations in the daily life; their impulsive, aggressive and disruptive behaviors will significantly decrease.

Barkley et al.(2000), in their study in which they tested the effectiveness of psychoeducational intervention programs for pre-school children who exhibit disruptive behavior disorder, supported the children attending kindergarten in different situations. These situations are; no intervention, family education, and full-day therapeutic intervention in the classroom. Children in different groups were monitored for nine months and, before and after the intervention, assessed through CBCL (The Child 
Behavior Checklist), TRF (Teacher Report Form) and the direct observation form. The research findings have indicated that the attention and aggression problems of the children who had been in the situation of full-day therapeutic approach have significantly decreased. These findings show that the psychoeducational intervention program implemented in the kindergarten can significantly reduce disruptive behaviors.

It has been determined in the literature that the problem solving skill programs have become effective in little children especially to reduce their extroversion problems (Mc Mahon, 2000). These educational intervention programs focus on general behavioral adaptation rather than behaviors such as aggression or violence. In another study, teachers were given training and a program-based intervention was implemented within the scope of a project aiming at supporting and improving pre-school children's resiliency. The children in this intervention program were given training on issues such as expressing their emotions, understanding others' emotions, communication skills, producing non-violent solutions to the problems in interpersonal relations, decision-making and competence skills. It was determined after the research that the extroversion problems of the children have decreased significantly (Dubas et al.1998, quoted by.Mc Mahon, 2000). Özcan (2007) has examined the effects of ICPS Program on 33 children with Attention Deficit Hyperactivity Disorder (ADHD). She found that ICPS training decreases ADHD symptomps as impulsivity and oversight, and also effects the agressive behavior, rulebreaking and introverted behaviors (Özcan and Öğ̈̈lmüş, 2010). Kargi (2009), tested the effectiveness of the Interpersonal Problem Solving Program (ICPS) in developing problem solving skills and reducing problem behaviours of 4 year old children who attend preschool. The study results show that the problem solving skills scores of the children who received interpersonal problem solving skills education were significantly higher than those of the children the control group and that the problem behaviours of the children in the experiment group reduced significantly. The findings demonstrate that interpersonal problem solving skills education given to children was effective in developing their problem solving skills and reducing their problem behaviours.

\section{DISCUSSION and CONCLUSION}

Along with the individual difficulties that the children who have behavioral and emotional problems and their families experience, the cost of mental health problems for the society is also high. In order to alleviate childhood mental problems, the intervention should start in early periods in which symptoms do not yet appear.

The pre-school years are critical years for development in terms of the development of communication, social interaction, language skills, and self-esteem. In the pre-school period, educational environments provide the child with opportunities such as social interaction, imitation and playmate ship, and adequate models to develop adaptive behaviors; in order for the child to develop his/her behavioral patterns (Odom, 2000).

Since they are critical years for development, monitoring and assessing children's behaviors in the preschool period are very important to support growth and to prevent possible problems (Weisz and Eastman, 1995; quoted by. Erol et al. 1998).

There are several School-based prevention programs for the emotional social development and preventing behavioral problems. The most notable exceptions in terms of popularity and empirical validity are I Can Problem Solve (ICPS; Spivack \& Shure, 1989), the extensive school-based preventive intervention for Promoting Alternative Thinking Strategies (PATHS) and Second Step apparently modeled after PATHS. PATHS and Second Step draw concepts and techniques from multiple theoretical frameworks. ICPS is based on social-cognitive theory. These programs have demonstrated effectiveness in promoting positive social behavior and reducing problem behavior in children in the early grades of elementary school (e.g., Izard, Trentacosta, King,\& Mostow, 2004). According to Jayanthi and Friend's reviews (2010), many techniques based work on problem solving have been suggested for successfully generating ideas. For example; rule out criticism, generate as many outrageous, offbeat ideas, combine and build on existing ideas, use a series of verbs such as magnify, minify, modify, use the technique of mental imagery and set a quota of ideas that need to be generated or set a limit for generating ideas.

ICPS intervention can provide children with skills to think about solving problems important to them when they are very young, and reduce and prevent early high-risk behaviors in ways that will increase their chance of success and social competence in junior high, high school, and beyond. 
The child learns the first social relations in the family. This relation is later developed and shaped through play and school environments. The findings of the studies conducted by Cohn, Patterson \& Christopoulous, (1991); Pettit and Mize, (1993); and Putallaz (1987) indicate that the parental and family love and support, and responsible family attitudes have effects on children such as having positive view of life and having positive expectations from their relations with others. Children who grow up in such family environments have high level of social competence and positive and accepting interactions with their peers. Maccoby (1996) highlighted the need for a "conceptual bridge" between intrafamily conflict and peer conflict. mothers' as well as fathers' marital aggression as important influences in children's aggressive problem solving ( e.g.,Duman \& Margolin, 2007).

In order to improve individual development and social acceptance, it is necessary for programs that support important competence skills such as analyzing the problems in interpersonal relations in a way in which both parties win, self-regulation, social competence, adaptive behavior, decision-making and resiliency to be started in the pre-school period with early training programs. It is essential that children are supported with preventive approaches on emotional and behavioral problems whether it be inside the family or in school. Teachers might also use the instrument to support their assessment of students. For example, they might collect anecdotal records, work samples or video of children

playing with a toy that has been found to increase thinking/learning, when assessing children's performance on cognitive standards - such as problem-solving, mathematical thinking or attention. They might observe and record children's use of a toy found to score high on creativity/imagination, when assessing standards related to selfexpression, pretend play or divergent thinking. When assessing interpersonal skills, they might observe children using toys found to increase social interaction. TrawickSmith,Russell \& Swaminathan (2011). In the context of preventive counseling services in schools, it will be beneficial for the development of children that programs like I Can Problem Solve (ICPS) are integrated into the curriculum and that teachers, families and children induce and apply to their lives such approaches. To reach this end, it is necessary, by being benefited from the contemporary literature, to develop programs that are culture and value specific, creative, effective, efficient, multi-module and supporting all areas of children's development.

\section{REFERENCES}

Barkley, R. A., Shelton, T.L., Crosswait, C., Moorehouse, M., Fletcher, K., Barett, S., Jenkins, L., \& Metevia, L.(2000). Multi-method psycho-educational intervention for preschool children with disruptive behavior: Preliminary results at post-treatment. Journal of Child Psychology and Psychiatry, 41, 319-332.

Dinçer, Ç. (1995). Anaokuluna devam eden 5 yaş grubu çocuklarına kişiler arası problem çözme becerilerinin kazandırılmasında eğitimin etkisinin incelenmesi. Yayımlanmamış doktora tezi, Hacettepe Üniversitesi Sağlık Bilimleri Enstitüsü.

Duman, S.,Margolin, G. (2007) Parents' aggressive influences and children's aggressive problem solutions with peers, Journal of Clinical Child \& Adolescent Psychology, 36, (1), 42-55.

Durlak, J.A. (1983). Social problem solving as a primary prevention strategy. Theory, research and practice. New York: Pergamon.

Erwin, G.P.(1993). Friendship and peer relations in children. Chichester:Wiley.

Erwin, G.P., Purves, G.D., \& Johannes, C.K. (2005). Involvement and outcomes in short-term interpersonal cognitive problem solving groups. Counselling Psychology Quarterly, 18(1), 41-46.

Fan, X \& Chen ,M. (2001). Parental involvement and students academic achievement. Educational Psychology Review, 13 (1), 20-21.

Gardner, H.(2006). Eğitimli akıl. İstanbul: Morpa Yayınları.

Heppner, P.P. (1987). An information processing approach to personal problem solving. Counselling Psychologist, 15, 371-447.

Hune, B.J. \& Nelson, M. C. (2002). Effects of teaching a problem-solving strategy on preschool children with problem behavior. Behavioral Disorders, 27(3), 185-207.

Izard, C.E , Trentacosta, C.J. , King, K.A. \& Mostow, A.J. (2004) An Emotion-Based Prevention Program for Head Start Children. Early Education and Development, 15(4), 407-422.

Jayanthi, M., Friend, M. (2010). Interpersonal problem solving: A selective literature review to guide practice: Journal of Educational and Psychological Consultation, 3, (1), 39-53.

Kargi, E. (2009). Bilişsel yaklaşıma dayalı kişilerarası sorun çözme becerileri kazandırma (BSÇ) programının etkililiği: Okul öncesi dönem çocukları üzerinde bir araştırma, Yayımlanmamış doktora tezi, Ankara Üniversitesi Eğitim Bilimleri Enstitüsü. 
Karpov, Y.V. (2003). Development through the life span: A neo-Vygotskian approach. Vygotsky's educational theory in cultural context. In A.Kozulin,B.Gindis, V.S.Ageyev, S.M.Miller Eds. New York: Cambridge Press.

Lochman ,J. E., Coie, J. D., Underwood, M. K. \& Terry, R. (1993). Effectiveness of a social relations intervention program for agressive and nonagressive, rejected children. Journal of Consulting and Clinical Psychology, 61, 1053-1058.

Loeber (1990). Development and risk factors of juvenile antisocial behaviour and delinquency. Clinical Psychology Review, 10, (1), 1-41.

Mc Mahon, S.D., Washburn, J., Felix, E.D., Yakın, J. \& Childrey, G. (2000). Violence prevention: Program effects on urban preschool and kindergarten children. Applied and Preventive Psychology, 9, 271-281.

Miller, P.H. (1993). Theories of developmental psychology. New York: W.H. Freeman Company.

Miller-Musun, L. (1993). Social acceptance and social problem solving in preschool children. Journal of Applied Developmental Psychology, 14, 59-70.

Oden, S. \& Asher, S. R. (1977). Coaching children in social skills for friendship making. Child Development, 48, 495-506.

Odom, S.L. (2000). Preschool inclusion: What we know and where we go from here. Topics in Early Childhood Special Education, 20, 20-27.

Öğülmüş, S. (2001). Kişiler arası sorun çözme becerileri ve eğitimi. Ankara: Nobel Yayıncılık.

Özcan, C. (2007). Kişilerarası Sorun Çözme Eğitiminin Dikkat Eksikliği Hiperaktivite Bozukluğu Olan Çocuklardaki Karşı Gelme Belirtileri Üzerine Etkileri, Hemşirelikte Doktora tezi, GATA Sağlık Bilimleri Enstitüsü, Ankara.

Özcan, C. \& Öğülmüş, S. (2010). "Dikkat Eksikliği Hiperaktivite Bozukluğu Olan Çocuklara Bilişsel Yaklaşıma Dayalı Kişilerarası Sorun Çözme Eğitiminin Katkıları”, TAF Preventive Medicine Bulletin, 9(4): 391-398.

Parker, J.G. \& Asher, S.R. (1987). Peer relations and later personel adjustment. Psychological Bulletin, 102, $357-$ 389.

Urbain;E.S. \& Kendall, P.C. (1980). Review of social cognitive problem solving interventions with children. Psychological Bulletin, 88, 109-143.

Shure, M. (2001). I Can Problem Solve (ICPS): An interpersonal cognitive problem solving program for children. Residential Treatment for Children \& Youth, 18(3), 3-14.

Shure, M. (1996). Raising a thinking child. New York: Henry Holt and Company, Inc.

Shure, M.(1992). I can problem solve: An interpersonal cognitive problem solving program (ICPS) preschool. Illinois, Champain: Research Press.

Shure, M.B. \& Spivack, G. (1982). Interpersonal problem solving in young children. A cognitive approach to prevention. American Journal of Community Psychology, 10, 341-356.

Trawick-Smith,J., Russell,H.,\& Swaminathan,S. (2011). Measuring the effects of toys on the problem-solving, creative and social behaviours of preschool children, Early Child Development and Care, 181 (7), 909-927.

Walker,H.M.,Colvin, G \& Ramsey, E. (1995). Antisocial behaviour in school.California:Pacific Grove.

Webster-Stratton, Reid. H. (2001). Social skills and problem solving training for children with early onset conduct problems: Who benefits? Journal of Child Psychology and Psychiatry, 42(7) 943-952.

Weisz, J. R., Suwanlert, S., Chaiyasit, W., Weiss, B., Achenbach, T. M. \& Trevathan, D. (1989). Epidemiology of behavioral and emotional problems among Thai and American Children: Teacher reports for ages 6-11. Journal of Child Psychology and Psychiatry, 30, 471-484.

Wittmer, D., Doll, B. \& Strain, P. (1996). Social and emotional development in early childhood: The identification of competence and disabilities. Journal of Early Interventions, 20(4), 299-317.

Zigler, E., Bella, D., Watson, N. (1972). Developmental and experiental determinations of self image disparity institutionalized and non institutionalized retarded and normal children. Journal of Personality and Social Psychology, 23,(1), 81-87. 